\title{
A Microcystic Adnexal Carcinoma in the Auditory Canal 15 Years after Radiotherapy of a 12-Year-Old Boy with Nasopharynx Carcinoma
}

\author{
Karl T. Beer' ${ }^{1}$ Sabine S. Bühler', Primus Mullis², R. Hubert Laeng ${ }^{3}$, Richard Greiner ${ }^{1}$
}

\begin{abstract}
Background: Radiogenic malignancies require cure of the primary disease and a prolonged survival. The introduction of high-volt technology in the 1950s and 1960s made radical radiotherapy feasible and successful in terms of higher cure rates and longer survival. We are already in a time when a higher number of patients with radiogenic secondary malignancies must be expected. Case Report: A 12-year-old boy is reported who suffered from an advanced nasopharynx carcinoma and was treated with radical irradiation in 1983. 15 years later he developed a rare microcystic adnexal carcinoma of the auditory canal inside the volume of the target dose. The secondary malignant neoplasm was resected and required another radiation treatment (1 Gy b.i.d.) due to involved margins.
\end{abstract}

Discussion and Literature Review: The entity of microcystic carcinoma is discussed with a review of the literature on biology, diagnosis, and treatment.

Key Words: Radiogenic malignancy · Pediatric nasopharynx carcinoma $\cdot$ Microcystic adnexal carcinoma $\cdot$ Reirradiation

Strahlenther Onkol 2005;181:405-10

DOI 10.1007/s00066-005-1323-9

\begin{abstract}
Mikrozystisches adnexales Karzinom des äußeren Gehörgangs 15 Jahre nach Radiotherapie eines 12-jährigen Patienten mit Nasopharynxkarzinom
\end{abstract}

Hintergrund: Radiogene Zweittumoren setzen Heilung der Ersterkrankung und langes Überleben voraus. Nach Einführung der Hochvolt-Strahlentherapie in den 50er und 60er Jahren wurden durch kurative Strahlentherapie höhere Heilungsraten und verlängertes Überleben ermöglicht. Wir kommen zu oder sind bereits in einer Zeit, in der mit erhöhter Wahrscheinlichkeit mit dem Auftreten radiogener Zweittumoren gerechnet werden muss.

Fallbericht: Berichtet wird über einen Patienten, der 1983 als 12-Jähriger wegen eines lokoregionär fortgeschrittenen Nasopharynxkarzinoms kurativ bestrahlt wurde und bei dem 15 Jahre später ein sehr seltenes mikrozystisches adnexales Karzinom des äußeren Gehörgangs im Volumen der Zieldosis diagnostiziert wurde. Die Zweitneoplasie wurde operiert und erforderte wegen R1-Resektion eine postoperative Radiotherapie (1 Gy b.i.d.).

Diskussion und Literaturübersicht: Die Entität des mikrozystischen Karzinoms wird mit einer Literaturübersicht in Bezug auf Biologie, Diagnose und Therapie diskutiert.

Schlüsselwörter: Radiogenes Zweitkarzinom · Pädiatrisches Nasopharynxkarzinom · Mikrozystisches Karzinom · Zweitbestrahlung

\footnotetext{
${ }^{1}$ Department of Radiation Oncology, Inselspital, University of Bern, Bern, Switzerland,

${ }^{2}$ Department of Pediatric Endocrinology, Inselspital, University of Bern, Bern, Switzerland,

${ }^{3}$ Institute of Pathology, Kantosspital Aarau, Aarau, Switzerland.
}

Received: May 25, 2004; accepted: March 24, 2005 


\section{Introduction}

Parallel to the technical development radical radiotherapy became more successful with the result of cure and longer survival time. Cure from the first malignancy and long survival are the preconditions for the development of a radiogenic secondary malignant neoplasm. Due to their longer life expectancy and their still growing organs children are particularly at risk $[8,15,25,27,31,33,36,38,40,42,45,46,57,59]$. As one of the most serious late sequelae of radiotherapy, secondary malignancies can develop after a long latent period [4, 10, 20]. Most literature is about secondary malignant neoplasms in Hodgkin's disease and brain tumors.

Nasopharynx carcinoma (NPC) in children is rare $[6,35$, 58] and often develops as a painless cervical swelling of enlarged, sometimes huge cervical lymph nodes. Epstein-Barr virus (EBV) infection is a known risk factor [41]. The 5-year overall survival rates are about 58\% [3]. The prognosis in children is independent of gender and race [35, 43]. Distant metastases can develop in up to $40 \%$ of patients [2, 19, 43, 44, 48]. The current standard treatment of NPC in children is simultaneous radiochemotherapy $[5,14,24,53,61]$.

We would like to report on a secondary malignancy 15 years after radical exclusive radiotherapy in a 12-year-old boy, who suffered from an advanced NPC. Written informed consent was obtained from the patient.

\section{Case Report}

Nasopharynx Carcinoma (NPC)

In 1983, a 12-year-old boy in good health and with an unremarkable personal history was sent to radiotherapy for a locoregionally advanced undifferentiated NPC, then called type Schmincke-Regaud. He presented with bilateral huge cervical lymph nodes. The CT demonstrated the primary tumor in the nasopharynx which reached far into the nasal cavity and into the oropharynx. Infiltration of the base of skull was confirmed by bone scintigraphy. The TNM category was cT3cN2M0 (UICC 1998).

Methods of radiotherapy for NPC. The portals were documented by simulation. Cobalt-60 $\left({ }^{60} \mathrm{Co}\right)$ photons were used for treatment. Lateral opposed fields included the base of skull and the regional levels II, III, and V. For level IV anteroposterior-posteroanterior (AP-PA) portals were used (Figure 1). For the phase after 39.6 Gy the portals for the primary tumor and cervical lymph nodes were split in order to spare the spinal cord. The fields were reduced posteriorly and supplemented by $9-\mathrm{MeV}$ electron fields. In the supraclavicular regions midline blocks were used after 39.6 Gy for spinal cord sparing. A total dose of $59.4 \mathrm{~Gy}$ on the $90 \%$ isodose was given for the primary tumor and the cervical lymph nodes, single dose was $1.8 \mathrm{~Gy}$. The supraclavicular region was irradiated to a total dose of 59.4 Gy on the ipsilateral left side and 50.4 Gy on the contralateral right side. The outer auditory canal was always included in the volume for the primary tumor and received a

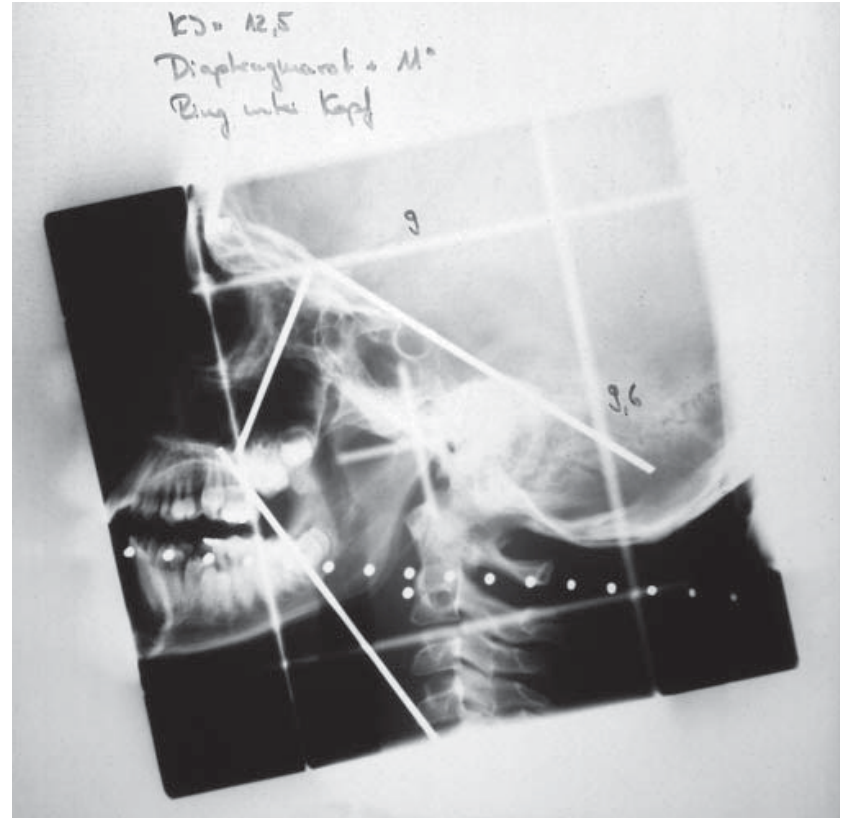

Figure 1. Lateral opposed simulator films of the first radiotherapy for nasopharynx carcinoma show the inclusion of the external auditory canal in the high-dose irradiation volume.

Abbildung 1. Seitlich opponierende Simulatoraufnahme der ersten Radiotherapie des Nasopharynxkarzinoms zeigen den Einschluss des äußeren Gehörganges in das Hochdosisvolumen.

dose of 66.6 Gy. No concomitant chemotherapy was given. A skin reaction grade 2 and a mucositis grade 3 developed.

Late effects of first radiotherapy. The NPC had remained in complete remission to date. The oral mucosa became atrophic and the patient lost his teeth as a consequence of xerostomia but did not suffer from severe side effects at first [17, 22, 23]. However, beginning in the 5 th year after radiotherapy the then 17-year-old boy became symptomatic from diverse severe and clinically evident late effects.

As the first symptom a left phrenicus paresis appeared. 1 year later a paresis of the right $\mathrm{N}$. V with dyskinesias occurred, and again 1 year later a right partial conduction deafness was diagnosed. At that time a hypoplasia of the ossicular chain bones and a marked atherosclerosis in both carotid arteries were shown on the CT scan. In the 8th year of follow-up an arterial hypertension was found. Meanwhile, the cervical spine had become heavily deformed (Figure 2), the right mandible hypotrophic and all cervical soft tissues atrophic.

In the 10th year after radiotherapy the meanwhile 22-year-old patient suffered from a thrombosis of the left jugular vein and the left brachiocephalic vein, and a collateral circulation in the upper thoracic aperture had developed (Figure 2). In both carotid arteries marked atherosclerosis was found $[9,50]$, and the patient was anticoagulated for the next 5 years. 
The radiotherapy had also caused endocrinological alterations, which were clinically not significant and were diagnosed only at the time when preparation for postoperative radiotherapy of the secondary malignant neoplasm was organized. Basal TSH (thyroid-stimulating hormone) was significantly increased to $12.7 \mathrm{mU} / 1$ (normal range, 0.35-4.5 mU/1) with an $\mathrm{FT}_{3}$ (free triiodothyronine) of $4.84 \mathrm{pmol} / 1$ (normal range, 3.5-6.5 pmol/l) and an $\mathrm{FT}_{4}$ (free thyroxine) of $10.7 \mathrm{pmol} / \mathrm{l}$, (normal range, 9.5-25 pmol/l). The TRH (thyrotropin-releasing hormone) profile showed a normal TSH response but an insufficient increase during the night. On sonography a small, hypotrophic thyroid gland with regressive alterations in both lobules was found, a further late side effect of radiotherapy. Those findings are indicative of a primary hypothyreosis and a small component of a secondary hypothyreosis caused by irradiation of the pituitary gland. A substitution with levothyroxine was initiated. The sex hormones showed the following baseline values: LH (luteinizing hormone) $10.8 \mathrm{U} / 1$ (normal range, 3-16 U/1), FSH (follicle-stimulating hormone) $24.9 \mathrm{U} / 1$ (normal range, 2-9 U/1), and testosterone $94.8 \mathrm{pmol} / \mathrm{l}$ (normal range, 66-142 pmol/1). Decreased stimulation indicated a dysfunction of Leydig cells. Caryotyping ruled out a Klinefelter syndrom, whereas alcohol abuse was considered the probable cause. The ACTH-cortisol axis and the growth hormone production were not involved.

13 years after treatment, a chronic eczema of the right external auditory canal was diagnosed for the first time, presumably the first hint at the later diagnosed secondary malignant neoplasm.

\section{Microcystic Adnexal Carcinoma (MAC)}

Diagnosis. In December 1998, 15 years after radiotherapy of the NPC, the meanwhile 28-year-old patient contacted his family practitioner because of increased pain in the right ear and progressive hearing loss. On clinical examination the right pinna was painful to touch and scaling crusts were found in the external auditory canal. A CT scan of the base of skull demonstrated a soft-tissue mass in the right external acoustic meatus extending to the right pyramid, and on the MRI scan a circular, contrast-enhancing infiltrating mass around the auditory canal was seen; suspect lymph nodes were not found. The first biopsy was diagnosed as a moderately differentiated squamous cell carcinoma.

Surgery. An extended lateral parotidectomy and a modified radical neck dissection of the levels II-IV were performed. The defect was closed with a flap of the pectoralis major muscle. The external auditory canal was reconstructed with a silicone catheter and a Thiersch graft. On the postoperative CT no macroscopic tumor rest was seen. The definitive histopathologic diagnosis described a typical MAC. The tumor showed a dissociated and infiltrating growth especially of the perineural sheaths, a focal squamous differentiation, and pseudoepi-

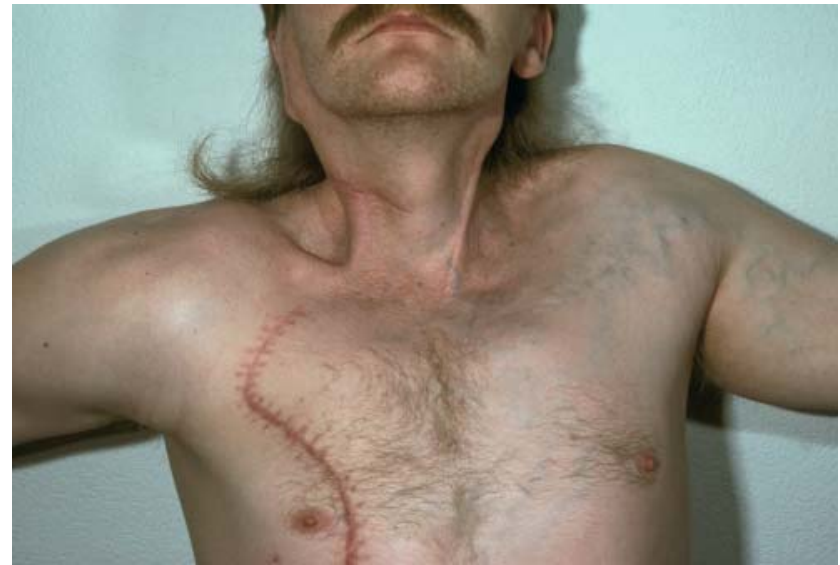

Figure 2. Musculoskeletal changes (atrophy of erector trunci muscles, kyphoscoliosis of the cervical spine), marked telangectasias in the previously irradiated regions, and extensive collateral circulation in the left thoracic aperture.

Abbildung 2. Muskuloskelettale Veränderungen (Atrophie des Erector trunci, Kyphoskoliose der HWS), deutliche Teleangiektasien der bestrahlten Regionen und ausgedehnter Kollateralkreislauf der linken Thoraxapertur.

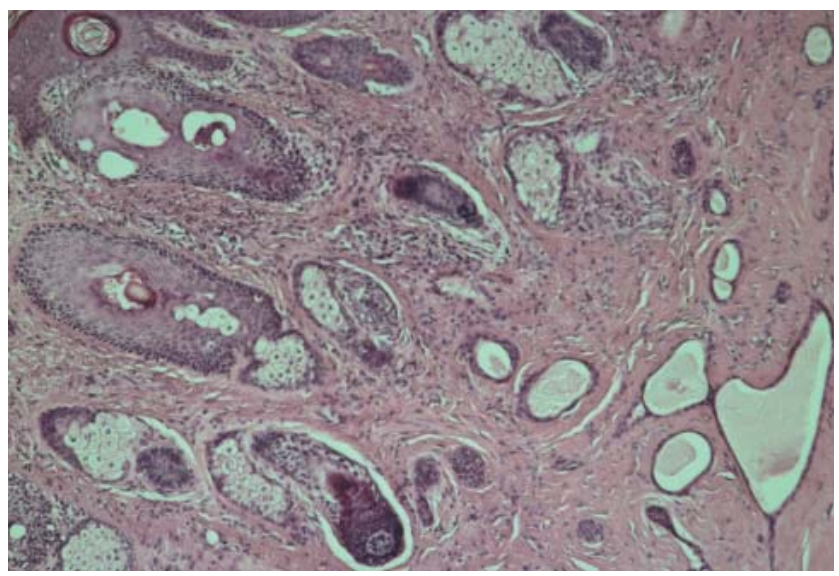

Figure 3. Histological specimen showing a typical microcystic adnexal skin carcinoma with extended dissociated and infiltrating growth, infiltration of perineural sheaths, focal squamous differentiation, and pseudoepitheliomatous hyperplasia, HE 25X.

Abbildung 3. Histologisches Präparat eines typischen mikrozystisch adnexalen Hautkarzinoms mit ausgedehntem dissoziierten und infiltrierenden Wachstum, Infiltration von Perineuralscheiden, fokal squamöser Differenzierung und pseudoepitheliomatöser Hyperplasie, HE $25 \times$.

theliomatous hyperplasia (Figure 3). 18 lymph nodes were free of metastases, but the carcinoma reached the resection margins (R1 resection). Concerning the former radiotherapy, significant alterations were seen in the dermis and the underlying layers. Because of the incomplete resection and the histological aggressiveness we decided for a second radical radiotherapy. 


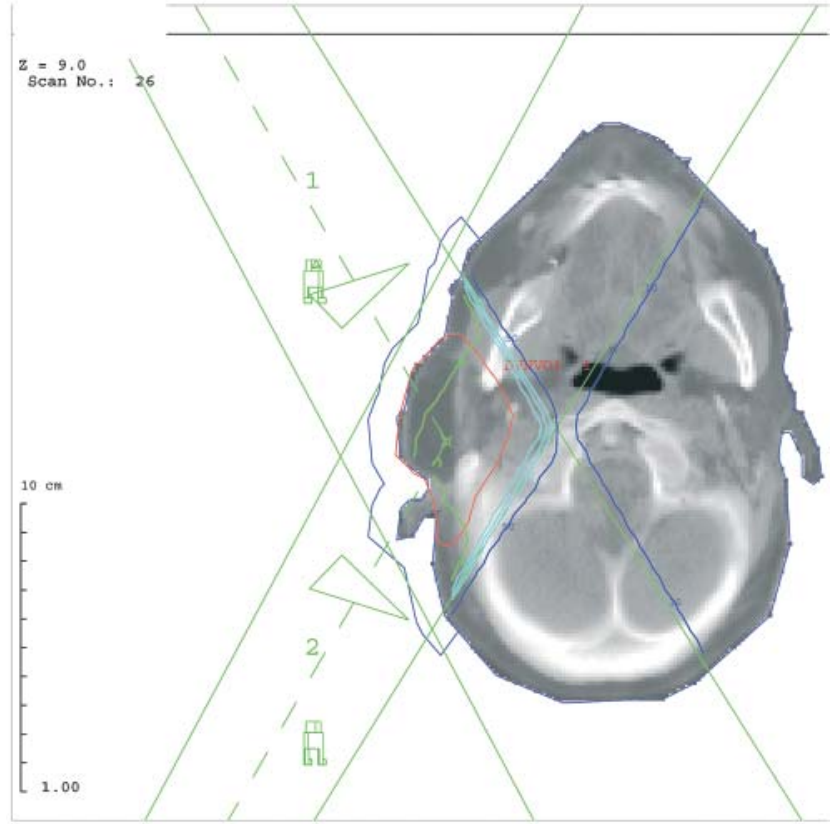

Figure 4. 3-D-planned dose distribution of convergent fields with delineation of planning target volume.

Abbildung 4. 3-D geplante Dosisverteilung mittels konvergierender Felder und Darstellung des PTV.

Radiotherapy for MAC. At referral for the second radiotherapy, the patient had a Karnofsky index of 90. His height was $163 \mathrm{~cm}$ (normal height in comparison with his siblings) and his weight $60 \mathrm{~kg}$. Blood pressure under medication was $120 / 80 \mathrm{mmHg}$. The flap in the right parotid region was healed, the patient had no immediate postoperative symptoms. Saliva production was reduced (unstimulated saliva flow $0.24 \mathrm{ml} /$ $\min$; stimulated $0.44 \mathrm{ml} / \mathrm{min}$ ) and, as a consequence, the patient was edentulous.

As our standard treatment for a second course of radical irradiation after a first full-course radiotherapy, we employed a 3-D-based bifractionated (1 Gy b.i.d.) regimen and applied a total dose of $66 \mathrm{~Gy}$ in the ICRU point. The clinical target volume (CTV) encompassed the former tumor region of the resected auditory canal and the first lymphatic drainage to the parotid and the level II area. An isocentric application technique at the linear accelerator was used with convergent fields of 6-MV photons (Figure 4).

Radiotherapy was not combined with simultaneous chemotherapy which does not seem effective for MAC.

The second radiation treatment was surprisingly well tolerated; acute skin and mucosal reactions did never exceed grade 2 and disappeared within 6 weeks.

The patient was last seen 66 months after the second radiotherapy. He was in a good performance status. The tumor remained in complete clinical and radiologic remission. The patient reported occasional slight pain when opening his mouth which was already reduced after the first treatment,

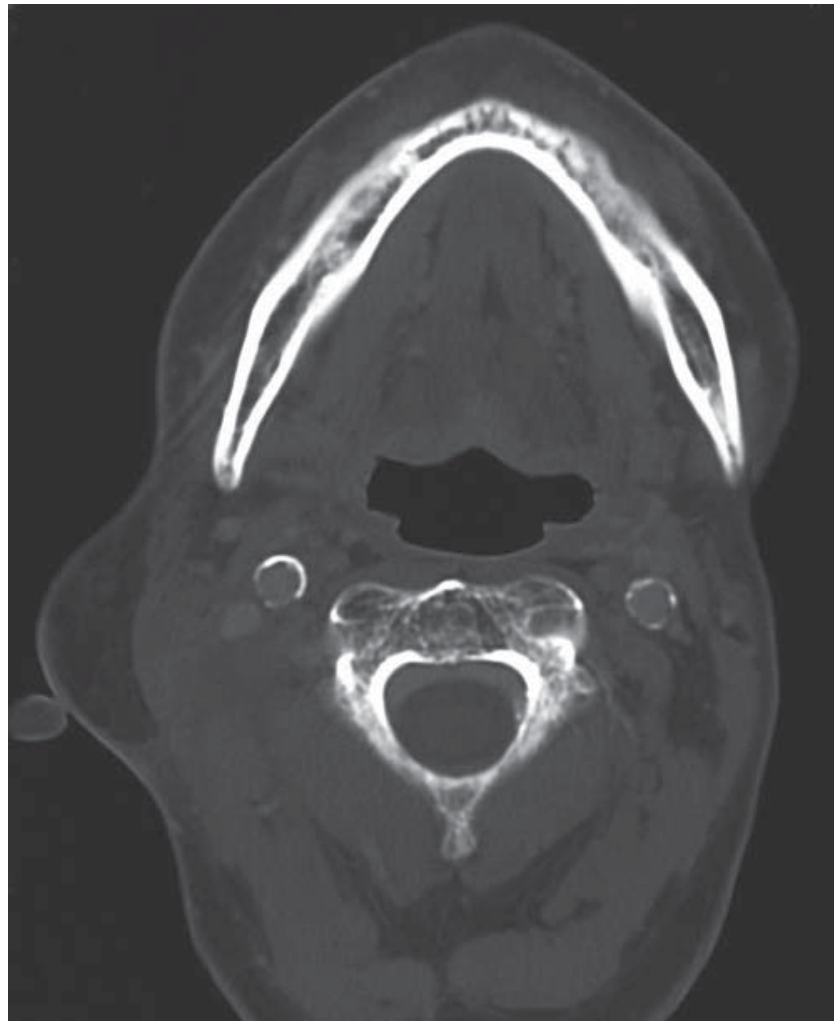

Figure 5. CT scan showing complete remission of the tumor with postradiotherapeutic alterations in the flap tissue and marked atherosclerotic lesions in the carotid arteries.

Abbildung 5. CT mit kompletter Remission des Tumors, post-radiogenen Veränderungen im Lappengewebe und deutlicher Atherosklerose in den Karotiden.

and discharge from the surgical scar. The last follow-up CT scan showed a complete remission, a fibrosis of the temporomandibular joint, and a streaky imbuement of the fatty tissues of the flap (Figure 5).

The most recent laboratory parameters included a macrocystic anemia (hemoglobin $105 \mathrm{~g} / \mathrm{l}$ ) probably as a consequence of chronic alcohol abuse. The substitution with levothyroxine was successful with a suppression of the basal TSH level to 0.003 and an increase in $\mathrm{FT}_{3}$ and $\mathrm{FT}_{4}$ to 6 and $24.2 \mathrm{pmol} / \mathrm{l}$, respectively.

\section{Discussion}

We report on a rare case of MAC in the auditory canal that developed 15 years after radical radiotherapy for an NPC in a then 12-year-old boy, who was a second time successfully treated by subradical surgery and postoperative irradiation.

Since NPC in children is a rare disease, few data on secondary tumors after radiotherapy of NPC in children are found.

MAC was first defined in 1982 by Goldstein et al. [21]. In the literature mostly case reports are described $[7,30,39,47$, 
49], but never as a secondary malignant neoplasm after radiotherapy for NPC.

In a larger series of 27 patients, Antley et al. [1] showed most tumors to be second carcinomas after a radical radiotherapy. The carcinomas developed up to 30-40 years after irradiation. Preferred localizations were centrofacial and cervical regions; involvement of the ear is only reported twice $[11,28]$.

At clinical examination most often asymptomatic slowly growing nodules or cyst-like tumors are found, some presenting with a scar-like appearance $[7,10]$. The tumor can be mistaken for other neoplasms, such as squamous cell carcinoma $[7,12,13,21]$ as in the first biopsy of our patient. There is a relationship of MAC with salivary and sweat gland tumors [60], since they share common histological features and chromosomal aberrations.

The MACs are locally invasive, destructive, and often infiltrate perineural sheaths [7]. It is difficult to obtain clean margins, as these tumors can spread far beyond the visible lesion [12]. They have a high recurrence rate; hematogenous metastases are rare [7, 20]. Surgery is recommended as the treatment of choice $[12,18]$, particularly Moh's microsurgery.

A gross tumor mass of MAC is commonly considered to be radioresistant [49]. A sequential treatment strategy of resection and radiotherapy is rational. For microscopic residual tumor the indication for radiotherapy is clearly given. This approach was validated in our case, in which the concept of a second radical radiotherapy 15 years after the first radical treatment was chosen instead of a further mutilating surgery followed by adjuvant radiotherapy $[16,26,29,32,34,37$, 51-56]. The risk paid off, the patient is now 6 years in a complete remission and has no additional serious side effects after the second radiation treatment regimen.

\section{References}

1. Antley CA, Carney M, Smoller BR. Microcystic adnexal carcinoma arising in the setting of previous radiation therapy. J Cutan Pathol 1999;26:48-50.

2. Bagatzounis A, Erakleous E, Michaelides I. Epidural metastasis in nasopharyngeal carcinoma. Strahlenther Onkol 2003;179:123-8.

3. Bailet JW, Mark RJ, Abemayor E, et al. Nasopharyngeal carcinoma: treatment results with primary radiation therapy. Laryngoscope 1992;102:965-72.

4. Beck JD. Secondary neoplasms in 5-year survivors of cancer in childhood: results of the Childhood Cancer Survivor Study. Strahlenther Onkol 2002; 178:167-8.

5. Beckmann G, Flentje M. Present status of treatment in nasopharyngeal carcinoma. Strahlenther Onkol 2003;179:283-91.

6. Benider A, Sahraoui S, Acharki A, et al. Carcinomas of the nasopharynx in children. Analysis of 50 cases. Bull Cancer 1995;82:155-61.

7. Billingsley EM, Fedok F, Maloney ME. MAC. Case report and review of the literature. Arch Otolaryngol Head Neck Surg 1996;122:179-82.

8. Bin-Abbas B, Mawlawi H, Sakati N, et al. Endocrine sequelae of childhood craniopharyngioma. J Pediatr Endocrinol Metab 2001;14:869-74.

9. Boerma M, Kruse JJ, van Loenen M, et al. Increased deposition of von Willebrand factor in the rat heart after local ionizing irradiation. Strahlenther Onkol 2004;180:109-16.

10. Borenstein A, Seidman DS, Trau H, et al. Microcystic adnexal carcinoma following radiotherapy in childhood. Am J Med Sci 1991;301:259-61.

11. Chi J, Jung YG, Rho YS, et al. Microcystic adnexal carcinoma of external auditory canal: report of a case. Otolaryngol Head Neck Surg 2002;127:241-2.
12. Chiller K, Passaro D, Scheuller M, et al. MAC: forty-eight cases, their treatment, and their outcome. Arch Dermatol 2000;136:1355-9.

13. Cook TF, Fosko SW. Unusual cutaneous malignancies. Semin Cutan Med Surg 1998;17:114-32.

14. Cooper JS, Lee H, Torrey M, et al. Improved outcome secondary to concurrent chemoradiotherapy for advanced carcinoma of the nasopharynx: preliminary corroboration of the Intergroup experience. Int $\mathrm{J}$ Radiat Oncol Biol Phys 2000;47:861-6.

15. Denys D, Kaste SC, Kuhn LE. The effects of radiation on craniofacial skeletal growth: a quantitative study. Int J Pediatr Otorhinolaryngol 1998; 45:7-13.

16. Eisbruch A, Dawson L. Re-irradiation of head and neck tumors. Benefits and toxicities. Hematol Oncol Clin North Am 1999;13:425-36.

17. Epstein JB, Emerton S, Lunn R, et al. Pretreatment assessment and dental management of patients with nasopharyngeal carcinoma. Oral Oncol 1999; 35:33-9.

18. Friedman PM, Friedman RH, Jiang SB, et al. Microcystic adnexal carcinoma: collaborative series review and update. J Am Acad Dermatol 1999;41:225-31.

19. Geara FB, Sanguineti G, Tucker SL, et al. Carcinoma of the nasopharynx treated by radiotherapy alone: determinants of distant metastasis and survival. Radiother Oncol 1997;43:53-61.

20. Gold DG, Neglia JP, Dusenbery KE. Second neoplasms after megavoltage radiation for pediatric tumors. Cancer 2003;97:2588-96.

21. Goldstein DJ, Barr RJ, Santa Cruz DJ. Microcystic adnexal carcinoma: a distinct clinicopathologic entity. Cancer 1982;50:566-72.

22. Grotz KA; Gemeinsame Stellungnahme der Deutschen Gesellschaft für Zahn-, Mund- und Kieferheilkunde; Deutschen Gesellschaft fur Radioonkologie, Medizinische Physik und Strahlenbiologie; Abstimmung mit dem Vorstand der Deutschen Gesellschaft fur Zahnerhaltungskunde. Dental care for patients with antineoplastic radiotherapy of the head and neck. Strahlenther Onkol 2003;179:275-8.

23. Grotz KA, Duschner H, Kutzner J, et al. New evidence for the etiology of so-called radiation caries. Proof for directed radiogenic damage of the enamel-dentin junction. Strahlenther Onkol 1997;173:668-76.

24. Gruner A, Grabenbauer GG, Rödel C, et al. Nasopharyngeal carcinoma: only irradiation or simultaneous radiochemotherapy? Strahlenther Onkol 1999; 175:591-619.

25. Habrand JL, Bondiau PY, Dupuis 0, et al. Late effects of radiotherapy in children. Cancer Radiother 1997;1:810-6.

26. Haraf DJ, Weichselbaum RR, Vokes EE. Re-irradiation with concomitant chemotherapy of unresectable recurrent head and neck cancer: a potentially curable disease. Ann Oncol 1996;7:913-8.

27. Herrmann T, Dorr W, Koy S, et al. Early loss of teeth after treatment for childhood leukemia. Strahlenther Onkol 2004;180:371-4.

28. Hunt JT, Stack BC Jr, Futran ND, et al. Pathologic quiz case 1. Microcystic adnexal carcinoma (MAC). Arch Otolaryngol Head Neck Surg 1995;121:1430-3.

29. Junker A. Tissue tolerance in repeat irradiation. Strahlenther Onkol 2001; 177:438-9.

30. Kirkland PM, Solomons NB, Ratcliffe NA. Microcystic adnexal carcinoma. J Laryngol Otol 1997;111:674-5.

31. Kroll SS, Woo SY, Santin A, et al. Long-term effects of radiotherapy administered in childhood for the treatment of malignant diseases. Ann Surg Oncol 1994:1:473-9.

32. Kuwert T. Diagnosis of recurrent or persistent nasopharyngeal cancers inspite of radiotherapy: comparison of F-18-deoxyglucose positron emission tomography with computed tomography. Strahlenther Onkol 1999;175:415.

33. Larson DL, Kroll S, Jaffe N, et al. Long-term effects of radiotherapy in childhood and adolescence. Am J Surg 1990;160:348-51.

34. Lengyel E, Baricza K, Somogyi A, et al. Reirradiation of locally recurrent nasopharyngeal carcinoma. Strahlenther Onkol 2003;179:298-305.

35. Martin WD, Shah KJ. Carcinoma of the nasopharynx in young patients. Int J Radiat Oncol Biol Phys 1994;28:991-9.

36. Marx M, Langer T, Beck JD, et al. Disorders of endocrine function after brain tumor therapy in childhood. Strahlenther Onkol 1999;175:305-8.

37. McLean M, Chow E, O'Sullivan B, et al. Re-irradiation for locally recurrent nasopharyngeal carcinoma. Radiother Oncol 1998;48:209-11.

38. Murray RD, Brennan BM, Rahim A, et al. Survivors of childhood cancer: long-term endocrine and metabolic problems dwarf the growth disturbance. Acta Paediatr Suppl 1999;88:5-12. 
39. Ohtsuka H, Nagamatsu S. Microcystic adnexal carcinoma: review of 51 Japanese patients. Dermatology 2002;204:190-3.

40. Pai HH, Thornton A, Katznelson L, et al. Hypothalamic/pituitary function following high-dose conformal radiotherapy to the base of skull: demonstration of a dose-effect relationship using dose-volume histogram analysis. Int J Radiat Oncol Biol Phys 2001;49:1079-92.

41. Pathmanathan R, Prasad U, Sadler R, et al. Clonal proliferations of cells infected with Epstein-Barr virus in preinvasive lesions related to nasopharyngeal carcinoma. N Engl J Med 1995;333:693-8.

42. Paulino AC, Simon JH, Zhen W, et al. Long-term effects in children treated with radiotherapy for head and neck rhabdomyosarcoma. Int J Radiat Oncol Biol Phys 2000;48:1489-95.

43. Perez CA. Carcinoma of the nasopharynx: factors affecting prognosis. Int $J$ Oncol Biol Phys 1992;23:271-80.

44. Petrovich Z, Cox JD, Middleton R, et al. Advanced carcinoma of the nasopharynx. 2. Pattern of failure in 256 patients. Radiol Oncol 1985;4:15-20.

45. Raney RB, Asmar L, Vassilopoulou-Sellin R, et al. Late complications of therapy in 213 children with localized, nonorbital soft-tissue sarcoma of the head and neck: a descriptive report from the Intergroup Rhabdomyosarcoma Studies (IRS)-II and -III. IRS Group of the Children's Cancer Group and the Pediatric Oncology Group. Med Pediatr Oncol 1999;33:362-71.

46. Roebuck DJ. Skeletal complications in pediatric oncology patients. Radiographics 1999;19:873-85.

47. Salvan D, Spatz A, Avril M, et al. [Microcystic sclerosing adnexal carcinoma: 2 case reports. Diagnostic and therapeutic difficulties.] Ann Otolaryngol Chir Cervicofac 1998;115:19-22.

48. Sanguinetti G, Geara FB, Garden AS, et al. Carcinoma of the nasopharynx treated by radiotherapy alone: determinants of local and regional control. Int J Radiat Oncol Biol Phys 1997;37:985-96.

49. Snow S, Madjar DD, Hardy S, et al. MAC: report of 13 cases and review of the literature. Dermatol Surg 2001;27:401-8.

50. So NM, Lam WW, Chook P, et al. Carotid intima-media thickness in patients with head and neck irradiation for the treatment of nasopharyngeal carcinoma. Eur J Radiol 2001;38:235-48.

51. Spencer SA, Wheeler RH, Peters GE, et al. Concomitant chemotherapy and re-irradiation as management for recurrent cancer of the head and neck. Am J Clin Oncol 1999;22:1-5.

52. Stevens KR Jr, Britsch A, Moss WT. High-dose re-irradiation of head and neck cancer with curative intent. Int J Radiation Oncology Biol Phys 1994; 29:687-98.
53. Stevens ME, Schaler RE, Harnsberger HR. Nasophayrnygeal cancer in childhood. Ear Nose Throat J 1987;66:104-6.

54. Studer G, Gratz KW, Glanzmann C. Osteoradionecrosis of the mandibula in patients treated with different fractionations. Strahlenther Onkol 2004; 180:233-40.

55. Tan EH, Adelstein DJ, Saxton JP, et al. Concurrent chemoradiotherapy for salvage in relapsed squamous cell head and neck cancers. Cancer Invest 1997;15:422-8.

56. Tercilla OF, Schmidt-Ulrich R, Wazer DE. Re-irradiation of head and neck neoplasms using a twice-a-day scheduling. Strahlenther Onkol 1993;169: 285-90.

57. Timmermann B, Kortmann RD, Kuhl J, et al. Interdisciplinary therapy of childhood ependymomas. Strahlenther Onkol 2002;178:469-79.

58. Uzel 0, Yoruk S0, Sahinler I, et al. Nasopharyngeal carcinoma in childhood: long-term results of 32 patients. Radiother Oncol 2000;58:137-41.

59. Wijers $0 \mathrm{~B}$, Levendag PC, Luyten GP, et al. Radiation-induced bilateral optic neuropathy in cancer of the nasopharynx. Case failure analysis and a review of the literature. Strahlenther Onkol 1999;175:21-7.

60. Wohlfahrt C, Ternesten A, Sahlin P, et al. Cytogenetic and fluorescence in situ hybridization analyses of a MAC with $\operatorname{del}(6)(q 23 q 25)$. Cancer Genet Cytogenet 1997;98:106-10.

61. Wolden SL, Steinherz PG, Kraus DH, et al. Improved long-term survival with combined modality therapy for pediatric nasopharynx cancer. Int J Radiat Oncol Biol Phys 2000;46:859-64.

\section{Address for Correspondence}

Karl T. Beer, MD

Radio-Onkologiezentrum Biel-Seeland-Berner Jura

Rebenweg 38

2501 Biel

Switzerland

Phone (+41/32) 366-8117

e-mail:karl.beer@radioonkologie.ch 